\title{
Risks to the offspring of patients with some common congenital heart defects*
}

\author{
N R DENNIS † AND JOAN WARREN
}

From the MRC Clinical Genetics Unit, Institute of Child Health, London WCIN IEH

SUMMARY The families of 424 adult index patients with ventricular septal defect, right ventricular outflow tract obstruction, or combinations of these two abnormalities, were visited and interviewed, and whenever possible the children of index patients were examined clinically.

Congenital heart defects were present in 9 of 308 children, 8 of 899 sibs, 4 of 840 parents, and 4 of 731 nephews and nieces of the index patients. The last three figures are likely to be underestimates owing to the design of the study.

Comparison of pairs of affected relatives suggests that the group of lesions studied may have genetic determinants in common.

With the introduction in the last 20 years of increasingly sophisticated methods of investigation and effective surgical treatment for many of the congenital heart malformations there is growing interest in the genetics of these conditions. In particular, the survivors of the early operations are now having children of their own, and may want to know the probability that their children will be similarly affected. We set out to add to the limited data available on the risk of ventricular septal defect, pulmonary valve stenosis, pulmonary infundibular stenosis, and combinations of these lesions, which include tetralogy of Fallot, in the offspring of patients, and we also took the opportunity to gather information on sibs and other relatives.

Pulmonary infundibular stenosis is a narrowing, which may result from hypoplasia or muscular hypertrophy, of the right ventricular outflow tract below the pulmonary valve. Tetralogy of Fallot is a combination of ventricular septal defect, dextroposition of the aorta, and right ventricular outflow tract obstruction usually at both infundibular and valve level. The embryological basis for tetralogy of Fallot may be abnormal rotation of the conus, with malpositioning of its septum (initially the bulbar septum, separating the outflow tracts of the developing ventricles). ${ }^{1}$

Several studies of sibs of index patients with

*Preliminary results of the study were published in Child AH, Dennis NR. The genetics of congenital heart disease. Birth Defects 1977; XIII, No 3A:85-91.

†Now at Division of Child Health, Southampton General Hospital and University of Southampton.

Received for publication 5 March 1980 various congenital heart malformations, including $\stackrel{\infty}{\rightarrow}$ those just mentioned, have been made (table 1). The methods used in these studies varied: in some information was collected by questionnaire, while in others the families were seen and relatives examined by the investigators. This variation probably accounts for some of the variations in the results quoted. Excluding syndrome associated defects (a minority in most categories) the recurrence risks observed were between 1 and $4 \%$ for all congenital heart defects, and around $1 / 3$ to $2 / 3$ of the recurrences were of the same anatomical type as in the index patient.

Information on the risk to offspring of patients with congenital heart defects is less extensive and is 3 . summarised in table 2. Methods again vary, but the $\delta$ study of Zetterquist ${ }^{7}$ appears particularly painstaking. The frequency of congenital heart disease 0 in the offspring was very similar to that reported in sibs, and again around $1 / 3$ to $2 / 3$ had anatomically $\frac{D}{O}$ similar defects to the affected parent.

In interpreting the findings of family studies, how- N ever, it is not always clear what are anatomically or $N$ embryologically related defects. For example, N isolated ventricular septal defect, a clinically useful $\underset{\sigma}{\omega}$ category, includes defects in different sites which may result from different developmental dis-

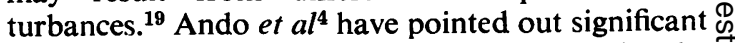
differences between the USA and Japan in the ${ }_{0}^{+}$ relative contributions of different anatomical varieties of ventricular septal defect to the total. Whether $\overrightarrow{\mathbb{D}}$ the differences are environmental or genetic in $\frac{?}{\mathbb{D}}$ origin, they underline the fact that the clinical $\frac{}{0}$ category is not homogeneous. 
TABLE 1 Percent affected of sibs of index patients with congenital heart disease in previous studies

\begin{tabular}{|c|c|c|c|c|}
\hline Lesion & Authors & $\begin{array}{l}\text { Index } \\
\text { patients }\end{array}$ & $\begin{array}{l}\text { Affected } \\
\text { Sibs }\end{array}$ & $\%$ \\
\hline AS & $\begin{array}{l}\text { Zoethout et al } 2 \\
\text { Nora et al } 3 \\
\text { Ando et } a l^{4}\end{array}$ & $\begin{array}{r}126 \\
135 \\
29\end{array}$ & $\frac{10 / 246}{2 / 41}$ & $\begin{array}{l}4 \cdot 1 \\
2 \cdot 2 \\
4 \cdot 9\end{array}$ \\
\hline PDA & $\begin{array}{l}\text { Polani and Campbells } \\
\text { Wilkins } 6 \\
\text { Nora et al }{ }^{3} \\
\text { Zetterquist }{ }^{7} \\
\text { Ando et } \text { al }^{4}\end{array}$ & $\begin{array}{l}261 \\
241 \\
204 \\
435 \\
295\end{array}$ & $\begin{array}{l}9 / ? \\
3 / 198 \\
\overline{15 / 663} \\
8 / 408\end{array}$ & $\begin{array}{l}2 \cdot 1 \\
1 \cdot 5 \\
3 \cdot 4 \\
2 \cdot 3 \\
2 \cdot 0\end{array}$ \\
\hline $\mathbf{C A}$ & $\begin{array}{l}\text { Campbell and Polani }{ }^{8} \\
\text { Nora } \text { et }^{\text {al }}{ }^{3} \\
\text { Zetterquist } \\
\text { Boon and Roberts }^{7}\end{array}$ & $\begin{array}{r}151 \\
128 \\
94 \\
100\end{array}$ & $\begin{array}{l}1 / 252 \\
-5 / 283 \\
1 / 212\end{array}$ & $\begin{array}{l}0.4 \\
1 \cdot 8 \\
1 \cdot 8 \\
0 \cdot 5\end{array}$ \\
\hline ASD & $\begin{array}{l}\text { Williamson } 10 \\
\text { Nora et } \text { al }^{3} \\
\text { Zetterquist } \\
\text { Sanchez Cascos } 11 \\
\text { Ando et } \text { al }^{4}\end{array}$ & $\begin{array}{r}135 \\
152 \\
191 \\
92 \\
557\end{array}$ & $\begin{array}{l}- \\
6 / 645 \\
11 / 335 \\
13 / 1110\end{array}$ & $\begin{array}{l}3 \cdot 7 \\
3 \cdot 2 \\
1 \cdot 0 \\
3 \cdot 3 \\
1 \cdot 2\end{array}$ \\
\hline VSD & $\begin{array}{l}\text { Campbell and Goodwin } 12 \\
\text { Nora et } a l^{3} \\
\text { Ando et } a^{4}\end{array}$ & $\begin{array}{r}180 \\
212 \\
1241\end{array}$ & $\frac{6 / 359}{18 / 1237}$ & $\begin{array}{l}1 \cdot 7 \\
4 \cdot 4 \\
1 \cdot 5\end{array}$ \\
\hline PS & $\begin{array}{l}\text { Campbell13 } \\
\text { Nora et } \text { al }^{3} \\
\text { Ando et } a^{4}\end{array}$ & $\begin{array}{l}125 \\
140 \\
123\end{array}$ & $\underbrace{6 / 282}_{3 / 199}$ & $\begin{array}{l}2 \cdot 1 \\
2 \cdot 9 \\
1 \cdot 5\end{array}$ \\
\hline TF & $\begin{array}{l}\text { Nora et al }{ }^{3} \\
\text { Sanchez Cascos } 14 \\
\text { Boon et al }{ }^{15} \\
\text { Ando et } \text { al }^{4}\end{array}$ & $\begin{array}{l}157 \\
113 \\
100 \\
296\end{array}$ & $\begin{array}{l}-2 / 161 \\
4 / 189 \\
6 / 380\end{array}$ & $\begin{array}{l}2 \cdot 7 \\
1 \cdot 1 \\
2 \cdot 1 \\
1 \cdot 6\end{array}$ \\
\hline Various & $\begin{array}{l}\text { Anderson } 16 \\
\text { Anderson } 16\end{array}$ & $\begin{array}{l}2000 \\
-\end{array}$ & $\begin{array}{c}76 / 5339 \\
4 / 59\end{array}$ & $\begin{array}{l}1 \cdot 4 \\
6 \cdot 8 *\end{array}$ \\
\hline
\end{tabular}

- Families where one parent and one sib already affected.

AS, aortic stenosis; PDA, persistent ductus arteriosus; CA, coarctation of aorta; ASD, atrial septal defect; VSD, ventricular septal defect; PS, pulmonary stenosis; PVS, pulmonary valve stenosis; PIS, pulmonary infundibular stenosis; TF, tetralogy of Fallot; Cath, cardiac catheter; OP, open heart operation; Clin, clinical PM, post mortem examination; RV, right ventricle; DC, death certificate.

Fuhrmann, ${ }^{20}$ and later using larger numbers, Fraser and Hunter ${ }^{21}$ argued that defects that occur in close relatives, even though they be different, are likely to have common genetic determinants, and by implication a similar morphogenetic origin. Fraser and Hunter ${ }^{21}$ collected from published reports 111 pairs of sibs with different congenital heart defects. They indicated an increased occurrence of pulmonary stenosis, transposition of the great vessels, and possibly ventricular septal defect, paired in the other sib with tetralogy of Fallot.

Patterson et $a^{22}$ have shown in Keeshond dogs that the heart malformations which are common in that breed can be arranged in order of increasing severity, from haemodynamically unimportant absence of the papillary muscle of the conus and minor anomalies of the conus septum, through isolated ventricular septal defect or pulmonary valve
TABLE 2 Percent affected of offspring of index patients with congenital heart disease in previous studies

\begin{tabular}{|c|c|c|c|c|}
\hline Lesion & Authors & $\begin{array}{l}\text { Index } \\
\text { pat:ents }\end{array}$ & $\begin{array}{l}\text { Affected } \\
\text { offspring }\end{array}$ & $\%$ \\
\hline AS & Nora et $a l^{3}$ & - & $4 / 103$ & 3.9 \\
\hline PDA & $\begin{array}{l}\text { Wilkins } 6 \\
\text { Zetterquist } 7 \\
\text { Nora and Nora } 17 \\
\text { Ando et } \text { al }^{4}\end{array}$ & $\begin{array}{l}86 \\
252 \\
-24\end{array}$ & $\begin{array}{c}3 / 179 \\
12 / 484 \\
6 / 139 \\
0 / 30\end{array}$ & $\begin{array}{l}1 \cdot 7 \\
2 \cdot 5 \\
4 \cdot 3 \\
-\end{array}$ \\
\hline CA & $\begin{array}{l}\text { Campbell and Polani }{ }^{8} \\
\text { Zetterquist }{ }^{7} \\
\text { Boon and Roberts } 9\end{array}$ & $\overline{-}$ & $\begin{array}{l}0 / 45 \\
5 / 191 \\
0 / 8\end{array}$ & $\overline{2 \cdot 6}$ \\
\hline ASD & $\begin{array}{l}\text { Williamson }{ }^{10} \\
\text { Nora et al }{ }^{18} \\
\text { Zetterquist } \\
\text { Ando et al }{ }^{4}\end{array}$ & $\begin{array}{r}45 \\
73 \\
-\end{array}$ & $\begin{array}{l}4 / 111 \\
5 / 190 \\
6 / 397 \\
8 / 252\end{array}$ & $\begin{array}{l}3 \cdot 6 \\
2 \cdot 6 \\
1 \cdot 5 \\
3 \cdot 3\end{array}$ \\
\hline VSD & $\begin{array}{l}\text { Nora and Nora }{ }^{17} \\
\text { Ando et al } 4\end{array}$ & $\overline{60}$ & $\begin{array}{l}7 / 174 \\
0 / 75\end{array}$ & $\begin{array}{l}4 \cdot 0 \\
-\end{array}$ \\
\hline PS & $\begin{array}{l}\text { Nora and Nora } 17 \\
\text { Ando et al }\end{array}$ & $\overline{13}$ & $\begin{array}{l}4 / 111 \\
0 / 15\end{array}$ & $\begin{array}{l}3 \cdot 6 \\
-\end{array}$ \\
\hline TF & $\begin{array}{l}\text { Nora and Nora } 17 \\
\text { Ando et al } 4\end{array}$ & - & $\begin{array}{l}6 / 141 \\
1 / 12\end{array}$ & $\begin{array}{l}4 \cdot 2 \\
8 \cdot 3\end{array}$ \\
\hline
\end{tabular}

stenosis, to a combination of these two lesions, resembling in its most severe form tetralogy of Fallot with pulmonary atresia. The results of breeding experiments were consistent with polygenic determination of a common liability to these different defects, increasing liability being expressed as increasing severity. The underlying morphogenetic disturbance probably affects the conotruncal septum. While these findings cannot be literally applied to man, they show that clinical and genetic or developmental categories may not coincide.

The diagnoses of ventricular septal defect, pulmonary valvar stenosis, pulmonary infundibular stenosis, and any combination of these three were chosen for the present study. The common clinical conditions thus included are ventricular septal defect, isolated pulmonary valvar stenosis, and tetralogy of Fallot.

\section{Patients and methods}

Index patients were identified among the records of the Hospital for Sick Children, Hammersmith Hospital, and University College Hospital, all of London, by examining those medical notes indexed as ventricular septal defect, tetralogy of Fallot, or pulmonary stenosis and by searching through lists, kept in the cardiology departments, of cardiac catheterisations and various types of heart operation. The hospital notes of each patient were examined for the patient's most recent address and the name and address of the general practitioner. Clinical, 
cardiac catheter, angiographic, and operative findings were noted.

Criteria for inclusion as an index patient were (1) born before 1 January 1960 and still alive or dead but with issue, (2) cardiac catheter, angiographic, or operative findings of pulmonary valvar or infundibular stenosis, ventricular septal defect, or any combination of these, (3) absence of transposition of the great vessels, atrioventricular canal defect, Down syndrome, any other known malformation syndrome associated with congenital heart disease (for example, Noonan syndrome), or any probable but hitherto unidentified malformation syndrome. Sometimes we saw the patients before excluding them as having syndromes. Patients who satisfied the criteria but also had the following were not excluded: secundum atrial septal defect, persistent ductus arteriosus, aberrant left subclavian artery, persistent left superior vena cava, coarctation of aorta, and aortic incompetence associated with a ventricular septal defect.

We wrote in the first instance to the patient's last recorded general practitioner, explaining the study and asking for family information. If the patient had moved or changed doctors, he or she was traced through the current family doctor via the NHS Central Register at Southport. In only a few cases was it necessary to write directly to the patient without first obtaining the consent of the current general practitioner.

Having contacted the patient we arranged a home visit, at which one of us took the family history, either from the patient or from the parents. If the patient had any children, one of us or a suitably experienced colleague examined each of them (peripheral pulses, precordial palpation, auscultation). Any children with possibly abnormal findings on this home examination were referred (with the agreement of the general practitioner) to a cardiologist. Any report of congenital heart disease in an index patient's sib, parent, nephew, or niece, and all stillbirths and childhood deaths among the sibs and offspring, were documented as fully as possible by obtaining clinical records or the death certificate. No attempt was made to interview or examine relatives other than children, so that these relatives were counted as affected only if a diagnosis had already been made, and then usually only if the interviewee (index patient or his parent) was aware of it.

Initially, 507 index patients were accepted for inclusion in the study. Of these patients, 78 were excluded for various reasons, shown in table 3 , leaving 429 ( 245 males and 184 females), 424 of whom were visited and interviewed. The remaining
TABLE 3 Index patients: reasons for exclusion

\begin{tabular}{lr}
\hline Number of index patients eligible for inclusion & 507 \\
Untraced & 28 \\
Dead without issue & 24 \\
Abroad & 12 \\
Refused to co-operate & 13 \\
In services & 1 \\
\hline Number of index patients included in study & 429 \\
\hline
\end{tabular}

five, four of whom did not agree to be visited and one who lived too far away, filled in a questionnaire.

It was possible to examine 265 of the 308 children. Of the 43 not examined, the parents of 12 children refused (although the general practitioners of six children reported them normal), 11 children were abroad (but believed healthy), two children were too young to be examined, and we were unable for various other reasons to see the remaining 12 children. The children not examined were all said to be well.

The index patients are divided for the purpose of analysis into five categories, and the number in each category is shown in table 4 . Category 5 , isolated pulmonary infundibular stenosis, contained only four index patients with no affected relatives and is not considered further. Thus the tables and results refer to a total of 305 children, the three children born to category 5 index patients having been excluded.

The index patients who had children are also listed by sex, date of birth, and diagnostic category in the appendix, together with the numbers, date of birth, and sex of offspring, distinguishing which of these also have congenital heart disease.

\section{Results}

MATERNAL AGE AND BIRTH ORDER

The maternal age distribution of the index patients is shown in table 5 compared with the population distribution for England and Wales, standardised

TABLE 4 Diagnostic categories of the index patients

Group 1 Ventricular septal defect 161

Group 2 Pulmonary valve stenosis, with or without infundibular stenosis, and ventricular septal defect $108 \underset{<}{\sigma}$

Group 3 Pulmonary infundibular stenosis with normal pulmonary valve and ventricular septal defect

Group 4 Pulmonary valve stenosis with or without infundibular stenosis, no ventricular septal defect

Group 5 Pulmonary infundibular stenosis with normal pulmonary valve, no ventricular septal defect

Total 
TABLE 5 Distribution by maternal age (0) compared with general population distribution standardised for birth order $(E)$ (for index patients born in or after 1945)

\begin{tabular}{llllllll}
\hline \multicolumn{3}{l}{ Maternal age } & \multicolumn{4}{c}{} & Total \\
\cline { 2 - 6 } & $15-19$ & $20-24$ & $25-29$ & $30-34$ & $35-39$ & $40+$ \\
\hline O & 14 & 92 & 106 & 59 & 33 & 11 & 315 \\
E & 13.07 & 93.70 & 103.70 & 63.98 & 31.45 & $9 \cdot 10$ & 315.00 \\
\hline
\end{tabular}

TABLE 6 Distribution by number of previous live born sibs $(O)$ compared with general population distribution standardised for maternal age $(E)$ (for index patients born in or after 1945)

\begin{tabular}{llllll}
\hline & \multicolumn{2}{c}{ Birth order } & & \multicolumn{2}{c}{ Total } \\
\cline { 2 - 5 } & 0 & 1 & 2 & $3+$ & \\
\hline O & 143 & 96 & 47 & 29 & 315 \\
E & 135.03 & 93.45 & 44.68 & 41.84 & 315.00 \\
\hline
\end{tabular}

for the birth order distribution of the index patients. Only index patients born in the years 1945 to 1959 are entered, and births in each of the three 5-year periods, 1945 to 1949,1950 to 1954 , and 1955 to 1959 , are compared with population data from the middle year of the period, that is 1947,1952 , and 1957. There is no significant difference between the index patient and the control distributions.

The birth order distribution of the index patients is compared in a similar fashion with the general population, standardised for maternal age, in table 6 . Fourth and higher births are grouped together. The excess of early and deficit of later births is just conventionally significant if the first three columns of the table are combined $\left(\chi^{2} 1 \mathrm{df}=4.601,0.05>\mathrm{p}\right.$ $>0.02)$, but not for the table as a whole $\left(\chi^{2} 3 \mathrm{df}=\right.$ $4 \cdot 544, \mathrm{p}>0 \cdot 2)$. The trend towards earlier birth order is present in each of the three 5-year groups, but is greatest in the period 1955 to 1959 and least in 1945 to 1949 . If the category 'three or more previous live births' is subdivided into three, four, and five or more previous births, the observed numbers are less than the expected in each of the subdivisions.

\section{TWINS}

Fifteen index patients were twin born. None of the co-twins was affected although two had died soon after birth.

Distribution of the 15 twin pairs according to zygosity and diagnostic group of the affected member is shown in table 7. The diagnosis of zygosity is that given to us by the family except for the three cases indicated where we were able to examine the co-twin.
TABLE 7 Details of twin pairs ascertained via index patients who were twins (none of the co-twins was affected)

\begin{tabular}{|c|c|c|c|c|c|}
\hline Diagnostic group & 1 & 2 & 3 & 4 & Total \\
\hline No of index patients & 161 & 108 & 59 & 97 & 425 \\
\hline \multicolumn{6}{|l|}{ Zygosity } \\
\hline DZlike sex & $2^{*}$ & 2 & - & 3 & 7 \\
\hline DZ unlike sex & 1 & 1 & 1 & 一 & 3 \\
\hline $\mathbf{M Z}$ male & - & - & - & - & 一 \\
\hline MZ female & 一 & - & $1^{*}$ & $1^{*}$ & 2 \\
\hline Like sex, not known & 1 & 1 & - & 1 & 3 \\
\hline Total & 4 & 4 & 2 & 5 & 15 \\
\hline
\end{tabular}

*Both twins examined ( 3 pairs)

\section{OFFSPRING OF INDEX PATIENTS}

Of the 305 children of the index patients, 145 boys and 160 girls, nine had congenital heart disease. The diagnosis in the nine affected children was made at necropsy in two, at operation in one, by cardiac catheter in three, and clinically in three. The clinical diagnoses were made by cardiologists who thought the children had significant, though mild, congenital heart defects. Children with heart murmurs thought to be innocent (14 males and 16 females) are not counted as affected.

The distribution of affected children by sex of index patient and child and type of defect present in the index patient is given in table 8. Details of the affected parent-child pairs are summarised in table 9 .

Among the offspring counted as unaffected, four (all female) had died, three at less than 2 days of age and one at 8 months. In addition, and not counted in the total of 305 children, four (three males, one female) were stillborn. Medical records and death or stillbirth certificates gave no indication of congenital heart disease.

TABLE 8 Index patients and their children by diagnostic group of index patient and sex

\begin{tabular}{lrrrrrrrrrr}
$\begin{array}{l}\text { Diagnostic } \\
\text { group }\end{array}$ & 1 & & 2 & & 3 & & 4 & & Total \\
\cline { 2 - 7 } & $M$ & $F$ & $M$ & $F$ & $M$ & $F$ & $M$ & $F$ & \\
\hline $\begin{array}{l}\text { No of index } \\
\text { patients }\end{array}$ & 91 & 70 & 61 & 47 & 34 & 25 & 57 & 40 & 425 \\
$\begin{array}{l}\text { No with } \\
\text { children }\end{array}$ & 31 & 22 & 20 & 19 & 16 & 6 & 21 & 22 & 157 \\
$\begin{array}{l}\text { Children } \\
\quad \begin{array}{l}\text { Sons } \\
\text { affected }\end{array}\end{array}$ & 28 & 20 & 18 & 18 & 15 & 6 & 18 & 22 & 145 \\
$\begin{array}{l}\text { Daughters } \\
\text { affected }\end{array}$ & 34 & 22 & 22 & 15 & 16 & 8 & 17 & 26 & 160 \\
$\begin{array}{l}\text { Total children } \\
\text { affected }\end{array}$ & 62 & 42 & 40 & 33 & 31 & 14 & 35 & 48 & 305 \\
& 1 & 1 & 2 & - & 1 & - & 1 & 3 & 9 \\
& $2 / 104$ & $2 / 73$ & $1 / 45$ & $4 / 83$ & \\
\hline
\end{tabular}


TABLE 9 Details of affected children

\begin{tabular}{|c|c|c|c|c|c|}
\hline Group & $\begin{array}{l}\text { Family } \\
\text { No }\end{array}$ & $\begin{array}{l}\text { Index } \\
\text { patient }\end{array}$ & $\begin{array}{l}\text { Lesion in } \\
\text { index patient }\end{array}$ & $\begin{array}{l}\text { Lesion in } \\
\text { child }\end{array}$ & Diagnosis \\
\hline 2 & 8 & Father & PVS, VSD & $\begin{array}{l}\text { Son PVS } \\
\text { Daughter } \\
\text { Patresia, VSD }\end{array}$ & $\begin{array}{l}\text { Cath } \\
\text { PM }\end{array}$ \\
\hline 3 & 16 & Father & PIS, VSD & $\begin{array}{l}\text { Daughter } \\
\text { Persistent truncus }\end{array}$ & Cath \\
\hline 4 & 28 & Father & PVS, ASD & Daughter ASD & Clin \\
\hline 1 & 29 & Father & VSD & $\begin{array}{l}\text { Daughter } \\
\text { VSD, PIS }\end{array}$ & OP \\
\hline 4 & 261 & Mother & PVS & Daughter PVS & Cath \\
\hline 4 & 286 & Mother & PVS & $\begin{array}{l}\text { Daughter } \\
\text { Patresia, } \\
\text { hypoplastic RV }\end{array}$ & $\mathbf{P M}$ \\
\hline $\begin{array}{l}4 \\
1\end{array}$ & $\begin{array}{l}315 \\
388\end{array}$ & $\begin{array}{l}\text { Mother } \\
\text { Mother }\end{array}$ & $\begin{array}{l}\text { PVS+ ASD } \\
\text { VSD }\end{array}$ & $\begin{array}{l}\text { Daughter VSD } \\
\text { Daughter PVS }\end{array}$ & $\underset{\text { Clin }}{\text { Clin }}$ \\
\hline
\end{tabular}

SIBS OF INDEX PATIENTS

The index patients had between them 899 brothers and sisters, of whom eight had satisfactorily documented congenital heart disease. Two sibships each contributed two index patients to the series and these sibships were counted twice, as is appropriate for multiple incomplete ascertainment. ${ }^{23}$ The diagnoses of the affected sibs were confirmed by cardiac catheter, operation, or necropsy findings in seven and by clinical examination by a paediatrician in the remaining one. The distribution of the affected sibs according to sex of the index patient and sib and diagnosis in the index patient is shown in table 10 . The characteristics of the affected sib pairs are summarised in table 11. In addition, the sister of one man with ventricular septal defect and pulmonary infundibular stenosis was said to have died from heart disease at 6 months, but records, including the death certificate, could not be traced, and the brother of a woman with pulmonary valve stenosis developed sudden severe congestive heart failure and died at 13 years of age having previously been healthy. The clinical diagnosis was cardiomyopathy but necropsy examination was not performed. Both of these are counted as unaffected.

Among sibs counted as unaffected, 22 (11 males

TABLE 10 Index patients and their sibs by diagnostic group of the index patient and sex

\begin{tabular}{|c|c|c|c|c|c|c|c|c|c|}
\hline \multirow{2}{*}{$\begin{array}{l}\text { Diagnostic } \\
\text { group }\end{array}$} & \multicolumn{2}{|l|}{$I$} & \multicolumn{2}{|l|}{2} & \multicolumn{2}{|l|}{3} & \multicolumn{2}{|l|}{4} & \multirow[t]{2}{*}{ Total } \\
\hline & $M$ & $F$ & $M$ & $\boldsymbol{F}$ & $M$ & $F$ & $M$ & $\boldsymbol{F}$ & \\
\hline Index patients & 91 & 70 & 61 & 47 & 34 & 25 & 57 & 40 & 425 \\
\hline $\begin{array}{l}\text { Brothers } \\
\text { affected }\end{array}$ & $\frac{88}{-}$ & $\begin{array}{r}94 \\
1\end{array}$ & $\begin{array}{r}59 \\
1\end{array}$ & 56 & 27 & $\underline{25}$ & $\underline{63}$ & $\begin{array}{r}51 \\
1\end{array}$ & $\begin{array}{r}463 \\
3\end{array}$ \\
\hline $\begin{array}{l}\text { Sisters } \\
\text { affected }\end{array}$ & $\begin{array}{r}92 \\
2\end{array}$ & $\underline{71}$ & $\underline{82}$ & $\begin{array}{r}49 \\
3\end{array}$ & 34 & 14 & 57 & 37 & $\begin{array}{r}436 \\
5\end{array}$ \\
\hline \multirow[t]{2}{*}{$\begin{array}{l}\text { Total } \\
\text { affected }\end{array}$} & $\begin{array}{r}180 \\
2\end{array}$ & $\begin{array}{r}165 \\
1\end{array}$ & $\begin{array}{r}141 \\
1\end{array}$ & $\begin{array}{r}105 \\
3\end{array}$ & 61 & 39 & $\underline{120}$ & $\begin{array}{r}88 \\
1\end{array}$ & $\begin{array}{r}899 \\
8\end{array}$ \\
\hline & \multicolumn{2}{|c|}{$3 / 345$} & \multicolumn{2}{|c|}{$4 / 246$} & \multicolumn{2}{|c|}{$0 / 100$} & \multicolumn{2}{|c|}{$1 / 208$} & \\
\hline
\end{tabular}

TABLE 11 Details of affected sibs

\begin{tabular}{|c|c|c|c|c|}
\hline Group & $\begin{array}{l}\text { Family } \\
\text { No }\end{array}$ & $\begin{array}{l}\text { Index } \\
\text { patient }\end{array}$ & $S i b$ & Diagnosis \\
\hline $\begin{array}{l}2 \\
1^{*} \\
1 \\
1 \\
2 \dagger \\
2 \\
4^{*} \\
2 \dagger\end{array}$ & $\begin{array}{l}185 \\
215 \\
235 \\
254 \\
276 \\
284 \\
322 \\
353\end{array}$ & $\begin{array}{l}\text { Male VSD, PVS } \\
\text { Male VSD } \\
\text { Male VSD } \\
\text { Female VSD } \\
\text { Female VSD, PVS } \\
\text { Female VSD, PVS } \\
\text { Female PVS } \\
\text { Female VSD, PVS }\end{array}$ & $\begin{array}{l}\text { Brother VSD } \\
\text { Sister PVS } \\
\text { Sister VSD } \\
\text { Brother TF } \\
\text { Sister VSD, PVS } \\
\text { Sister PVS } \\
\text { Brother VSD } \\
\text { Sister VSD, PVS }\end{array}$ & $\begin{array}{l}\text { Cath } \\
\text { OP } \\
\text { Clin } \\
\text { OP } \\
\text { OP } \\
\text { PM } \\
\text { OP } \\
\text { OP }\end{array}$ \\
\hline
\end{tabular}

and three females) died later. In addition, and not $\infty$ counted in the total of 899 sibs, 17 (11 males and $\vec{\infty}_{\infty}$ six females) were stillborn. Documentation was poor 0 for stillbirths, but the death certificate or medical ${ }_{-}^{\circ}$ record was obtained for 14 of the 22 infant deaths $\vec{T}$ and eight of the nine later deaths, and none gave any $\mathbb{D}$ indication of congenital heart disease.

\section{PARENTS}

Of the 840 parents of index patients for whom in- $\ddot{\bullet}$ formation was available, four were said to have had ${ }^{-}$ congenital heart disease which we were able to confirm from the death certificate or medical records. The lesions in these parents and the index patients to whom they relate are summarised in table 12 .

\section{OTHER RELATIVES}

In a total of 731 nephews and nieces, four were affected. One was an operative diagnosis, one postmortem, and two clinical. Details are given in table 13 .

TABLE 12 Details of affected parents

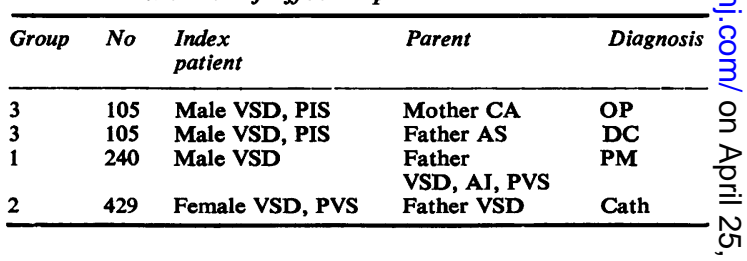

TABLE 13 Details of affected nephews and nieces

\begin{tabular}{lcllll}
\hline Group & No & $\begin{array}{l}\text { Index } \\
\text { patient }\end{array}$ & Relative & Diagnosis \\
\hline 1 & 32 & Male VSD & $\begin{array}{l}\text { Sister's daughter } \\
\text { PVS, VSD } \\
\text { Brother's daughter } \\
\text { PVS, VSD }\end{array}$ & OP \\
1 & 64 & Male PVS & $\begin{array}{l}\text { Sister's daughter } \\
\text { single ventricle } \\
\text { Sister's daughter } \\
\text { VSD }\end{array}$ & PM \\
1 & 70 & Male VSD & Female VSD & &
\end{tabular}




\section{Discussion}

The number of our index patients who were twin born, 15 of 429 , is a little higher than the expected 1 in $40,{ }^{24}$ but not significantly so. When corrected for the increased stillbirth and perinatal mortality rate of twins, ${ }^{25}$ which will lead to their being under represented in any group ascertained after infancy, the raised frequency of twins becomes significant at the $5 \%$ level. Only two of the 15 pairs of twins ascertained through an index patient were classed as monozygous, but ten of the 13 'dizygous' pairs, nine of which were so classified on the basis of family history alone, were like sexed, suggesting that some of the 'dizygous' pairs were wrongly classified by their families. An excess of monozygous twins among congenital heart disease index patients has been noted by Campbell, ${ }^{26}$ Myrianthopoulos, ${ }^{27}$ and Anderson. ${ }^{28}$

The proportion of affected offspring with congenital heart disease of all types in the four diagnostic categories together was nine of $305(2.9 \%)$ or, counting only those children personally examined, nine of $265(3.4 \%)$. This is comparable with the results of Nora and Nora ${ }^{17}$ who found four of 111 offspring affected in their pulmonary stenosis series, seven of 174 in ventricular septal defect, and six of 141 in tetralogy of Fallot. These figures also refer to congenital heart disease of all types but most were stated to be of the same type as in the index patient. Although the ascertainment of index patients is not described in detail in their paper, these authors did examine all the children, so that there are probably no major methodological differences between their study and ours.

We are unable to account for the fact that eight of the nine affected children were girls. It may be a chance finding. The probability of finding eight or nine girls or boys in nine affected is 1 in $25 \cdot 6$. The stillbirths, childhood deaths, and innocent murmurs were equally divided between boys and girls, which does not suggest that these categories contain significant numbers of undiagnosed affected sons.

The frequency of congenital heart disease observed in the sibs and nephews and nieces of the index patients is not significantly different from the prevalence at birth in the general population $(0.6$ to $0.8 \%){ }^{29-31}$ The low recurrence risk observed in the sibs (average $0.9 \%$ ) compared with the offspring is difficult to account for by a genetic explanation and probably reflects incomplete diagnosis in this group, many of whom were born over 30 years ago. The $\mathbf{4 8}$ stillborn or dead sibs could harbour enough undiagnosed cases to bring the true risk near to that of the offspring, even though documentation of the cause of death was obtained in approximately two thirds. In addition, some stillbirths and infant deaths may have been unreported to us, especially when family information was obtained from the older index patients themselves rather than from their mothers. The observed infant death rate was $2.4 \%$ and the general population rate for England and Wales from the Registrar General's Statistical Reviews $^{32}$ weighted for the number of index patients born in each year is $3.5 \%$. This suggests that some dead affected sibs were not reported to us at all rather than that they were reported as dead and unaffected.

The recurrence risks observed in this and other studies are compatible with previous suggestions of multifactorial inheritance for isolated congenital heart defects, ${ }^{33}$ with a genetic predisposition determined by contributions from several loci. More reliable data on sibs and second and third degree relatives would have been valuable in testing this hypothesis, or perhaps in pointing to a single major gene effect in some families, but owing to the nature of the study which set out to obtain information on children of patients, the diagnostic criteria applied to other groups of relatives could not be as complete as in the children.

Specific gene loci concerned with liability to the varieties of congenital heart disease examined here have not been identified, but this may become possible if a small number of them account for most of the effect. A search for HLA associations in a rather small and heterogeneous series of patients ${ }^{34}$ showed an increased frequency of the A2 antigen, but this awaits confirmation.

From tables 9, 11, 12, and 13 it can be seen that 23 pairs of affected relatives were detected, of whom six shared the same lesion, while in nine there was a common defect but one of the pair had an extra defect. In this latter group the unshared lesion was always a ventricular septal defect where both had some form of pulmonary stenosis, or else pulmonary valve or infundibular stenosis where both had a ventricular septal defect.

Eight pairs of relatives had apparently dissimilar lesions. These included three pairs where one had a ventricular septal defect and the other pulmonary valve stenosis (two of the diagnoses were clinical). In addition, a father with pulmonary infundibular stenosis and ventricular septal defect had a daughter with a persistent truncus arteriosus, a father with pulmonary valve stenosis and atrial septal defect had a daughter with an atrial septal defect (clinical diagnosis), an uncle with a ventricular septal defect had a niece with a single ventricle, and a man with ventricular septal defect and pulmonary infundibular stenosis had a father with congenital aortic stenosis and a mother with coarctation of the aorta. 
Thus, examination of the malformations present in pairs of affected relatives in our study tends to support the suggestion of Fraser and Hunter ${ }^{21}$ that there are genetic determinants common to pulmonary valve stenosis, ventricular septal defect, and tetralogy of Fallot, although we did not find any affected relatives with transposition of the great vessels. In other words, there may be in man, as in the Keeshond $\mathrm{dog}$, a related group of malformations involving development of the conotruncal septum, which can be expressed as ventricular septal defect, or right ventricular outflow tract obstruction at valve or infundibular level, or combinations of the two, and possibly persistent truncus arteriosus (see our family 16 , table 9 , and van Mierop et $\mathrm{al}^{35}$ ). This idea would run counter to the status of tetralogy of Fallot as a separate embryological entity, or alternatively, suggest that cases with this clinical label may be a heterogeneous group.

Miller and Smith $^{36}$ have recently published pedigrees suggesting single gene inheritance of what they called 'conotruncal malformation complex', corresponding to the group of malformations discussed above. It is possible that in some cases these malformations are determined by single genes of large effect but, as Miller and Smith point out, such cases must be comparatively rare.

Future studies of this sort should make the fullest possible use of anatomical and embryological splitting of the broad clinical groupings to try to show to what extent the more carefully defined subgroups correspond to genetic entities. The approach of comparing lesions in pairs of affected relatives may make a useful contribution to clarifying the embryological and genetic relationships between different congenital heart defects, if the numbers are large enough, and if a precise and standardised descriptive terminology is adopted.

We are grateful to the cardiologists who allowed us to study the families of their patients, and particularly to Dr R E Bonham-Carter, Professor J F Goodwin, Dr C M Oakley, Dr K A Hallidie-Smith, and Dr A Hollman. We thank the families and their general practitioners for their co-operation and help and those paediatricians and cardiologists who gave us their opinion on the possibly affected relatives.

Professor C O Carter suggested the need for this study and was most generous with help and encouragement throughout it. Mrs K A Evans was involved in the planning and management of the study, and allowed us to draw on her time, energy, and experience. Miss R Coffey, Dr F Howard, Dr E Ives, Dr T Mazurczak, and Dr G Pescia all made helpful contributions.

\section{References}

1 Becker AE, Connor M, Anderson RH. Tetralogy of $\overrightarrow{\overline{\vec{c}}}$ Fallot: a morphometric and geometric study. Am J Cardiol 1975;35:402-12.

2 Zoethout HE, Bonham-Carter RE, Carter CO. A family $\frac{\overline{\bar{C}}}{\overline{\mathrm{D}}}$ study of aortic stenosis. J Med Genet 1964;1:2-9.

3 Nora JJ, McGill CW, McNamara DG. Empiric recurrence risks in common and uncommon congenital heart $\frac{\Omega}{\infty}$
lesions. Teratology 1970;3:325-9.

4 Ando M, Takao A, Mori K. Genetic and environmental $\vec{\circ}$ factors in congenital heart disease. In: Inouye $\mathrm{E}$, Nishi- ${ }_{-}$ mura $\mathrm{H}$, eds. Gene-environment interaction in common $\overrightarrow{\vec{\omega}}$ diseases. Baltimore, London, Tokyo: University Park Press, 1977:71-88.

5 Polani PE, Campbell M. Factors in the causation of

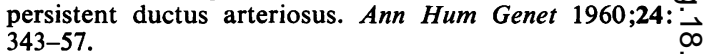
6 Wilkins JL. Risks to offspring of patients with patent $\frac{\infty}{\infty}$

7 Zetterquist P. A clinical and genetic study of congenital 을 heart defect. Institute of Medical Genetics, University of Uppsala, Uppsala, 1972.

8 Campbell M, Polani P. The aetiology of coarctation of the $\mathbb{D}$ aorta. Lancet 1961 ; i:463-8.

9 Boon AR, Roberts DF. A family study of coarctation of the aorta. J Med Genet 1976;13:420-33.

10 Williamson EM. A family study of atrial septal defect. $\rightarrow$ J Med Genet 1969;6:255-61.

11 Sanchez Cascos A. Genetics of atrial septal defect. Arch Dis Child 1972;47:581-8.

12 Campbell M, Goodwin JF. Some factors in the aetiology of ventricular septal defect. Prog Cardiovasc Dis 1965;7: 417-33.

13 Campbell M. Factors in the aetiology of pulmonary stenosis. Br Heart J 1962;24:625-32.

14 Sanchez Cascos A. Genetics of Fallot's tetralogy. $\mathrm{Br} \cong$ Heart J 1971 ;33:899-904.

15 Boon AR, Farmer MB, Roberts DF. A family study of 3 Fallot's tetralogy. J Med Genet 1972;9:179-92.

16 Anderson RC. Fetal and infant death, twinning and cardiac malformations in families of 2000 children with and 500 without cardiac defects. Am J Cardiol 1976;38: 218-24.

17 Nora JJ, Nora AH. Recurrence risks in children having one parent with a congenital heart disease. Circulation 3 . 1976;53:701-2.

18 Nora JJ, Dodd PF, McNamara DG, et al. Risk to off- 을 spring of parents with congenital heart defects. JAMA

19 Goor DA, Edwards JE, Lillehei CW. The development of interventricular septum of the human heart; cor- $\frac{T}{O}$ relative morphogenetic study. Chest $1970 ; 58: 453-68$.

20 Fuhrmann W. Congenital heart disease in sibships $N$ ascertained by two affected siblings. Humangenetik 1968;

6:1-12.
21 Fraser FC, Hunter ADW. Etiologic relations among $\mathrm{N}$ categories of congenital heart malformations. Am J W Cardiol $1975 ; 36: 793-5$.

22 Patterson DF, Pyle RL, Van Mierop L, Melbin J, Olson M. Hereditary defects of the conotruncal septum in Keeshond dogs. Pathological and genetic studies. Am $J \mathscr{\Omega}$ Cardiol 1974;34:187-205.

23 Steinberg AG. Methodology in human genetics. Am J T Hum Genet 1959;11:315-34.

24 Office of Population Censuses and Surveys. Birth $\mathbb{D}$ Statistics Series FM1 No 3. London: HMSO, 1976:50.

25 Bulmer MG. The biology of twinning in man. Oxford: Clarendon Press, 1970. 
26 Campbell M. Twins and congenital heart disease. Acta Genet Med Gemellol (Roma) 1961 ;10:443-55.

27 Myrianthopoulos NC. Congenital malformations in twins. Epidemiologic survey. Birth Defects 1975;11(8): 1-39.

28 Anderson RC. Congenital cardiac malformations in 109 sets of twins and triplets. Am J Cardiol 1977;39:1045-50.

${ }^{29}$ Mitchell SC, Korones SB, Berendes HW. Congenital heart disease in 56109 births. Circulation 1971;43:323-32.

30 Kenna HP, Smithells RW, Fielding DW. Congenital heart disease in Liverpool 1960-69. Q J Med 1975;44:17-44.

31 Bound JP, Logan WFWE. Incidence of congenital heart disease in Blackpool. Br Heart J 1977;39:445-50.

32 Registrar General's Statistical Reviews of England and Wales. London: HMSO, 1937 (part I, table 3), 1947 (table KK), 1952 (table HH), 1957 (table HH), 1970 (part I, table 3).
33 Nora JJ, Nora AH. The evolution of specific genetic and environmental counselling in congenital heart diseases. Circulation 1978;57:205-13.

34 Buc M, Nyulassy S, Stefanovic J, Jakubcova I, Benedelcova $\mathrm{M}$. HL-A2 and congenital heart malformations. Tissue Antigens 1975;5:128-30.

35 Van Mierop LHS, Patterson DF, Schnarr WR. Pathogenesis of persistent truncus arteriosus in light of observations made in a dog embryo with the anomaly. $\mathrm{Am}$ $J$ Cardiol 1978;41:755-62.

36 Miller ME, Smith DW. Conotruncal malformation complex: examples of possible monogenic inheritance. Pediatrics 1979;63:890-3.

Requests for reprints to Dr N R Dennis, Department of Child Health, Southampton General Hospital, Shirley, Southampton SO9 4XY.

APPENDIX

$T$, index patient one of twins; italics, affected; [ ]twins; sb=stillbirth.

\begin{tabular}{|c|c|c|c|c|c|c|c|}
\hline $\begin{array}{l}\text { Serial } \\
\text { No }\end{array}$ & $D O B$ & Group & Children of index patients & $\begin{array}{l}\text { Serial } \\
\text { No }\end{array}$ & $D O B$ & Group & Children of index patients \\
\hline \multicolumn{4}{|c|}{ MALE INDEX PATIENTS } & 61 & $10 / 46$ & 1 & F1/74;F5/76 \\
\hline 1 & $4 / 09$ & 3 & $\mathrm{M} 6 / 37 ; \mathrm{F} 4 / 42 ; \mathrm{M} 9 / 48$ & 62 & $1 / 47$ & 4 & M7/75 \\
\hline 2 & $3 / 14$ & 5 & M4/45;M2/49 & 65 & $4 / 47$ & 3 & M6/75 \\
\hline 3 & $5 / 15$ & 3 & $\mathrm{M} 11 / 50 ; \mathrm{F} 8 / 52$ & 67 & $4 / 47$ & 2 & M3/73;M6/75 \\
\hline 4 & $9 / 16 \mathrm{~T}$ & 2 & $\mathrm{~F}-/ 55 ; \mathrm{M} ;-/ 57$ & 69 & $5 / 47$ & 4 & F11/68;M5/74 \\
\hline 5 & $11 / 16$ & 4 & M11/47;M6/49;M10/50;F5/54 & 70 & $6 / 47$ & 1 & $\mathrm{M} 10 / 74 ; \mathrm{F} 5 / 77$ \\
\hline 6 & $5 / 17$ & 2 & F9/44(d24h);M-/51;F-/53 & 72 & $6 / 47$ & 1 & F5/72 \\
\hline 7 & $6 / 20$ & 2 & F $9 / 49 ; F 11 / 53$ & 75 & $7 / 47$ & 2 & M4/72;M2/74 \\
\hline 8 & $11 / 23$ & 2 & $\mathrm{~F} 11 / 57 ; \mathrm{F} 12 / 59 ; F-/ 60 ; M 2 / 66 ; \mathrm{F} 5 / 68$ & 77 & $9 / 47 \mathrm{~T}$ & 4 & F12/73 \\
\hline 9 & $11 / 24$ & 1 & M8/61;M5/63 & 78 & $11 / 47$ & 4 & F6/68;F1/71 \\
\hline 10 & $11 / 24$ & 2 & $\mathrm{M} 10 / 54 ; \mathrm{F} 5 / 60$ & 79 & $12 / 47$ & 1 & $\mathrm{M} 10 / 73 ; \mathrm{F} 9 / 76$ \\
\hline 11 & $12 / 25$ & 1 & $\mathrm{M} 6 / 62 ; \mathrm{M} 10 / 65$ & 81 & $12 / 47$ & 3 & M12/71 \\
\hline 12 & $12 / 26$ & 4 & $\mathrm{M} 12 / 55 ; \mathrm{F} 11 / 59$ & 82 & $12 / 47$ & 1 & $\mathrm{~F} 10 / 70 ; \mathrm{F} 8 / 72 ; \mathrm{F} 2 / 77$ \\
\hline 13 & $9 / 27$ & 4 & M7/62 & 83 & $1 / 48$ & 1 & F9/71;M8/73 \\
\hline 14 & $10 / 27$ & 1 & $\mathrm{M}-159 ; \mathrm{F}-/ 62$ & 84 & $1 / 48$ & 4 & F6/72 \\
\hline 15 & $3 / 28$ & 2 & $\mathrm{M} 2 / 56$ & 85 & $2 / 48$ & 1 & $\mathrm{M}-/ 70 ; \mathrm{M}-/ 72$ \\
\hline 16 & $12 / 28$ & 3 & $\mathrm{~F} 9 / 56 ; \mathrm{Fsb} / 58 ; \mathrm{F} 5 / 60 ; \mathrm{F} 10 / 62 ; \mathrm{M} 11 / 63$ & 86 & $4 / 48$ & 4 & M1/73 \\
\hline 19 & $8 / 30$ & 3 & F3/67 & 89 & $5 / 48$ & 1 & $\mathrm{~F} 10 / 71 ; \mathrm{F} 1 / 73$ \\
\hline 21 & $5 / 31$ & 2 & F9/54;F2/61 & 90 & $6 / 48$ & 3 & F2/73 \\
\hline 23 & $12 / 32$ & 2 & $\mathrm{~F}-167 ; \mathrm{F}-/ 72$ & 91 & $6 / 48$ & 1 & $\mathrm{~F} 4 / 71 ; \mathrm{F} 11 / 73$ \\
\hline 24 & $1 / 33$ & 4 & M3/59 & 95 & $10 / 48$ & 3 & M7/69;F9/72 \\
\hline 25 & $3 / 34$ & 1 & F11/58;F9/60;M3/68 & 103 & $4 / 49$ & 1 & F $10 / 75$ \\
\hline 26 & $4 / 34$ & 2 & $\mathrm{~F} 1 / 62 ; \mathrm{M} 4 / 64$ & 104 & $5 / 49$ & 2 & M10/73;F2/76 \\
\hline 28 & $9 / 34$ & 4 & $F 8 / 64 ; \mathrm{F} 9 / 68$ & 107 & $6 / 49$ & 1 & $\mathrm{M}-/ 69 ; \mathrm{M}-/ 72 ; \mathrm{M} 6 / 75$ \\
\hline 29 & $1 / 36$ & 1 & $\mathrm{M} 8 / 61 ; \mathrm{F} 1 / 63 ; \mathrm{F} 8 / 64 ; \mathrm{F} 6 / 66 ; F 2 / 73$ & 108 & $8 / 49$ & 3 & M1/73;F5/74 \\
\hline 30 & $2 / 36$ & $i$ & $\mathrm{~F} 10 / 58 ; \mathrm{M} 4 / 69 ; \mathrm{F} 7 / 72$ & 113 & $12 / 49$ & 1 & F11/74 \\
\hline 31 & $3 / 37$ & 1 & M1/65;F3/67 & 126 & $12 / 50$ & 1 & $\mathrm{M} 12 / 71 ; \mathrm{F} 1 / 74$ \\
\hline 32 & $8 / 37$ & 1 & F1/60;M1/64 & 127 & $2 / 51$ & 3 & {$[\mathrm{~F} 1 / 70 ; \mathrm{F} 1 / 70]$} \\
\hline 33 & $2 / 38$ & 4 & M4/62 & 131 & $5 / 51$ & 2 & M5/72 \\
\hline 34 & $6 / 38$ & 4 & {$[\mathrm{M} 1 / 67 ; \mathrm{M} 1 / 67] ; \mathrm{M}-/ 70$} & 132 & $5 / 51$ & 3 & F9/73;F11/75 \\
\hline 37 & $12 / 40$ & 3 & M5/68;M12/70 & 134 & $5 / 51$ & 1 & Msb/72;M11/74 \\
\hline 38 & $2 / 42$ & 3 & $\mathrm{M} 12 / 68 ; \mathrm{M} 6 / 70 ; \mathrm{F} 12 / 74$ & 138 & $6 / 51$ & 2 & $\mathrm{M} 6 / 72$ \\
\hline 39 & $3 / 42$ & 1 & M11/66;F4/70 & 144 & $1 / 52$ & 1 & $\mathrm{~F} 4 / 73 ; \mathrm{F} 1 / 76$ \\
\hline 40 & $10 / 42$ & 4 & $\mathrm{M}-/ 64 ; \mathrm{F}-/ 67$ & 145 & $1 / 52$ & 1 & M3/76;F9/77 \\
\hline 41 & $2 / 43$ & 1 & F2/68;M6/76 & 155 & $5 / 52$ & 1 & M5/75;M6/76 \\
\hline 42 & $4 / 43$ & 4 & $\mathrm{~F} 6 / 69 ; \mathrm{F} 4 / 71$ & 157 & $6 / 52$ & 2 & M10/75 \\
\hline 43 & $5 / 43$ & 4 & M3/69;F7/72 & 178 & $11 / 53$ & 2 & F4/74;M9/75;M7/77 \\
\hline 44 & $8 / 43$ & 2 & F4/68 & 180 & $11 / 53$ & 1 & F5/75 \\
\hline 46 & $12 / 43$ & 1 & M10/74;M9/76 & 185 & $1 / 54$ & 2 & F5/75 \\
\hline 47 & $7 / 44$ & 4 & $\mathrm{~F}-/ 70 ; \mathrm{M}-/ 72$ & 189 & $5 / 54$ & 3 & F3/76 \\
\hline 49 & $1 / 45$ & 4 & F2/66 & 193 & $6 / 54$ & 1 & F9/76 \\
\hline 50 & $4 / 45$ & 3 & $\mathrm{~F} 8 / 70 ; \mathrm{M} 10 / 72$ & \multirow{2}{*}{\multicolumn{4}{|c|}{ FEMALE INDEX PATIENTS }} \\
\hline 52 & $9 / 45$ & 4 & $\mathrm{F9} / 70 ; \mathrm{M6} / 75$ & & & & \\
\hline 53 & $10 / 45$ & 2 & M10/65;F3/67 & 246 & $4 / 15$ & 4 & $\mathrm{~F} 8 / 40 ; \mathrm{F} 1 / 43(\mathrm{~d} 8 \mathrm{mth})$ \\
\hline 54 & $12 / 45$ & 3 & $\mathrm{M} 4 / 72 ; \mathrm{M} 3 / 76$ & 247 & $2 / 24$ & 1 & $\mathrm{~F}-/ 50 ; \mathrm{M}-/ 51 ; \mathrm{F}-/ 56$ \\
\hline 55 & $12 / 45$ & 4 & M5/71 & 248 & $12 / 24$ & 1 & F3/50;F11/57;M5/53 \\
\hline 56 & $4 / 46$ & 2 & $\mathrm{M} 11 / 65 ; \mathrm{F} 11 / 72 ; \mathrm{F} 12 / 74$ & 250 & $5 / 28$ & 4 & $\mathrm{~F}-/ 53 ; \mathrm{F}-/ 58$ \\
\hline 57 & $4 / 46$ & 4 & F7/74 & 251 & $3 / 31$ & 1 & M7/49;M3/51 \\
\hline 58 & $9 / 46$ & 1 & M9/77 & 252 & $5 / 31$ & 2 & $\mathrm{~F} 7 / 59[\mathrm{M} 1 / 68 ; \mathrm{F} 1 / 68]$ \\
\hline
\end{tabular}


APPENDIX-continued

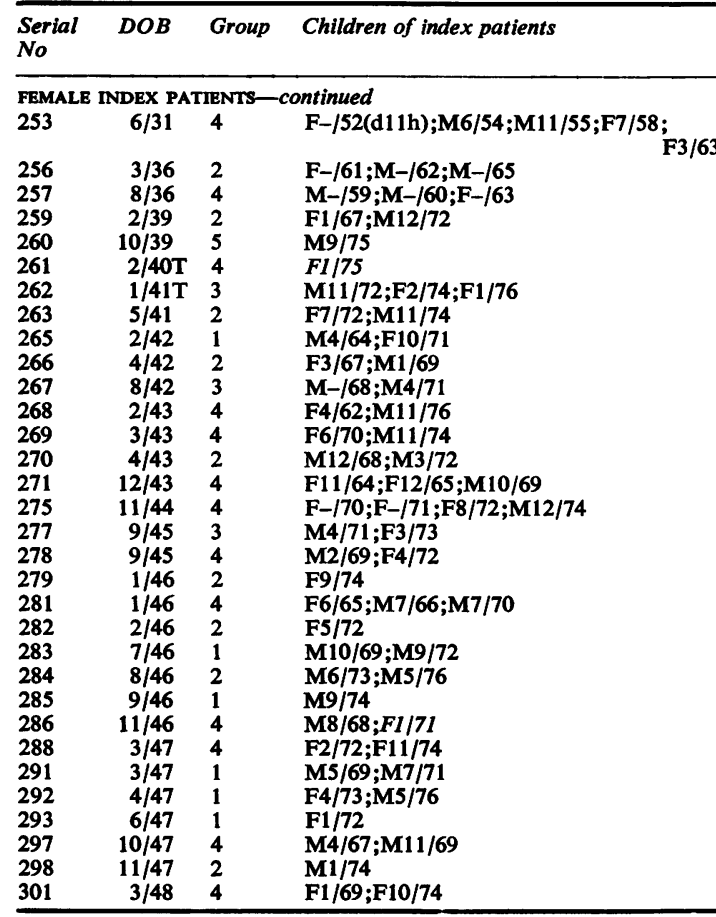

\begin{tabular}{|c|c|c|c|}
\hline $\begin{array}{l}\text { Serial } \\
\text { No }\end{array}$ & $D O B$ & Group & Children of index patients \\
\hline \multicolumn{4}{|c|}{ FEMALE INDEX PATIENTS—continued } \\
\hline \multirow{2}{*}{302} & $3 / 48$ & 3 & M11/69;M-/71;F3/75 \\
\hline & $10 / 48$ & 1 & $\mathrm{~F} 1 / 66 ; \mathrm{F} 3 / 67 ; \mathrm{F} 4 / 69 ; \mathrm{Msb} 1 / 71 ; \mathrm{F} 3 / 72 ;$ \\
\hline 306 & $11 / 48$ & 1 & F2/75 \\
\hline 308 & $5 / 49$ & 4 & M2/70;F4/75 \\
\hline 309 & $5 / 49$ & 2 & M9/70;M2/74 \\
\hline 310 & $8 / 49$ & $\mathbf{1}$ & M6/71;M2/75 \\
\hline 312 & $8 / 49$ & 3 & $\mathrm{~F} 10 / 70 ; \mathrm{F} 10 / 75(\mathrm{~d} 26 \mathrm{~h})$ \\
\hline 314 & $1 / 50$ & 4 & $\mathrm{~F} 4 / 71 ; \mathrm{M} 4 / 72$ \\
\hline 315 & $2 / 50$ & 4 & $F 2 / 70$ \\
\hline 316 & $2 / 50$ & 1 & M8/73;F3/76 \\
\hline 318 & $4 / 50$ & 4 & M1/73;M11/74 \\
\hline 319 & $4 / 50$ & 3 & F- $/ 69 ; \mathrm{F}-/ 71$ \\
\hline 324 & $1 / 51 \mathrm{~T}$ & 1 & $\mathrm{~F}-/ 73 ; \mathrm{F} 11 / 75$ \\
\hline 325 & $2 / 51$ & 2 & F1/73 \\
\hline 326 & $2 / 51$ & $\mathbf{1}$ & $\mathrm{M11} / 73 ; \mathrm{F} 9 / 75$ \\
\hline 330 & $8 / 51$ & i & M8/75 \\
\hline 331 & $8 / 51$ & 4 & M9/73;M8/76 \\
\hline 339 & $4 / 52$ & 4 & M6/74 \\
\hline 346 & $10 / 52$ & 2 & F6/77 \\
\hline 356 & $4 / 53$ & 2 & F4/75;F2/76 \\
\hline 362 & $7 / 53$ & 2 & M12/70;M10/72;M10/75 \\
\hline 364 & $8 / 53$ & 4 & M4/75 \\
\hline 368 & $12 / 53$ & 1 & M2/75 \\
\hline 369 & $12 / 53$ & 2 & F5/75 \\
\hline 374 & $2 / 54$ & 2 & M10/72;F2/75 \\
\hline 385 & $9 / 54$ & 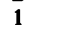 & $\mathrm{M} 6 / 73 ; \mathrm{F} 4 / 76$ \\
\hline 387 & $11 / 54$ & 2 & M12/74 \\
\hline 388 & $12 / 54$ & 1 & Msb10/73;F10/74 \\
\hline 392 & $6 / 55 \mathrm{~T}$ & 1 & F7/76 \\
\hline 399 & $2 / 56$ & 1 & F1/75;F10/77 \\
\hline 404 & $7 / 56$ & 2 & F12/75 \\
\hline 420 & $4 / 58$ & 1 & M5/75;F5/77 \\
\hline
\end{tabular}

